\title{
維持透析患者における冠血流予備能の検討
}

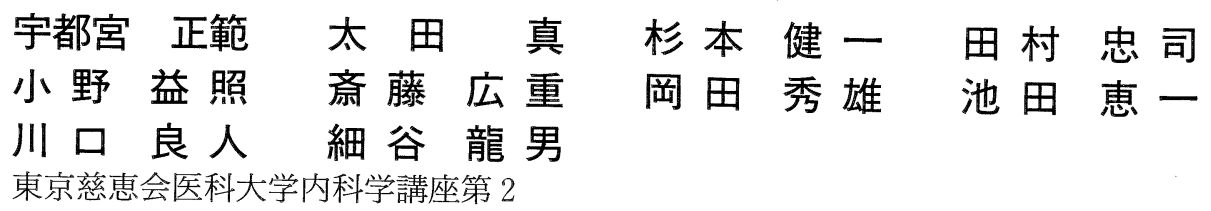

key words：維持透析，冠動脈硬化症，冠血流予備能，ドプラーガイドワイヤー

〈要旨〉

透析患者における冠循環動態を明らかにするために，ドプラーガイドワイヤーを用いて冠血流速および冠血流予 備能を測定し患者背景因子と比較検討した。対象は胸痛を主訴として来院した血液透析患者で, 症状あるいは運動 負荷心電図から虚血性心疾患が疑われて冠動脈造影を施行し，冠動脈本幹に $25 \%$ 以上の狭窄を認めなかった 7 例 で，平均年齢は 58 歳，平均透析期間は 94 か月である。 これに対し，対照例は同様に冠動脈本幹に $25 \%$ 以上の狭窄 を認めなかった非腎不全患者 8 例とした。

冠動脈血流速の計測は, ドプラーガイドワイヤーを左前下行枝近位部に留置し, パルス・ドプラー法にて行った. 安静時の冠血流速は硝酸イソソルビド $2.5 \mathrm{mg}$ 冠動脈注入後に計測し, 平均最大流速 (APV), 瞬間最大流速(MPV), 拡張期と収縮期の平均流速の比(DSVR)の 3 つの指標を記録した。冠血流予備能は, 塩酸パパベリン $10 \mathrm{mg}$ 冠動脈 注入後に最大冠拡張が得られた状態での APV と安静時の APV の比として求めた。また，全例にMモード心エコー 図および血液生化学検査を施行した。

安静時の APV および MPV は，透析患者が対照患者に比較して有意に高值を呈していたが，塩酸パパペリン 10 mg 冠動脈注入後の APV および MPV は, 両群間において有意差を認めなかった. 冠血流予備能は透析患者が $2.3 \pm$ 0.7 で, 対照患者 $(3.9 \pm 0.6)$ に比べ有意に低值であった。 また，透析患者は左室重量係数が大きく，賓血状態にあ ることが観察された

以上より，透析患者は冠血流予備能が低下しており， その原因には安静時冠血流速の増大が重要であると考えら れた。

\section{Analysis of coronary flow reserve using Doppler guide wire in patients with chronic renal replacement therapy}

Masanori Utsunomiya, Makoto Ohta, Kenichi Sugimoto, Tadashi Tamura, Masuteru Ono, Hiroshige Saito, Hideo Okada, Keiichi Ikeda, Yoshindo Kawaguchi, Tatsuo Hosoya

Department of Internal Medicine (II), The Jikei University School of Medicine

To investigate the coronary blood flow dynamics in dialysis patients, we measured the coronary blood flow velocity and coronary flow reserve using Doppler guide wire. We studied 7 dialysis patients who had no significant coronary artery stenosis, but were suspected of ischemic heart disease due to their clinical symptoms and electrocardiographic findings. Mean age was 58 years old and mean duration of dialysis was 94 months. Eight non-uremic sujects who had no significant coronary artery stenosis served as controls.

Using Doppler guide wire in the proximal left anterior descending artery, we analyzed the average peak velocity (APV), maximum peak velocity (MPV), and diastolic/systolic velocity ratio (DSVR) at baseline and a hyperemic stage. Coronary flow reserve was assessed by the ratio of flow velocity change induced by papaver. ine hydrocloride $(10 \mathrm{mg}$ ).

The APV and MPV at the baseline of dialysis patients were significantly higher than those of the control

宇都宮正範 東京慈恵会医科大学内科学講座第 2 $\bar{\top}$ 105-8471 港区西新橋 3-25-8（03-3433-1111）

Masanori Utsunomiya Fax 03-3433-4297

〔受付：平成 9 年 11 月 19 日, 受理：平成 10 年 2 月 9 日〕 
patients. The coronary flow reserve of dialysis patients $(2.3 \pm 0.7)$ was lower than that of the control patients (3.9土0.6).

In conclusion, coronary flow reserve of dialysis patients was lower than that of the control patients due to high APV.

\section{緒言}

近年，透析患者の高齢化や透析期間の長期化，糖尿 病性腎症の急増に伴い，様々な心血管系合併症が問題 となっており, 透析患者の生命予後を大きく左右して いる ${ }^{1)}$. また，透析患者は複数の冠危険因子を合併して いる場合が多く, 腎性貧血, 左室肥大, 動静脈シャン トなど特殊な病態も併せ持ち, 冠微小循環障害の心筋 虚血に対する関与も示唆される。一方, ドプラーガイ ドワイヤー (FloWire, Cardiometrics 社製) の開発に より, 冠血流速測定が可能となり冠動脈の予備能も評 価されるに至ったが2), 透析患者における冠血流速や 冠血流予備能（coronary flow reserve）に関する報告 はない.

本論文は，透析患者における冠循環動態を明らかに するため, ドプラーガイドワイヤーを用いて冠血流速 および冠血流予備能を測定し患者背景因子と比較検討 した。

\section{I 、対象および方法}

\section{1. 対 象}

1994 年 5 月から 1997 年 9 月まで, 当院に胸痛を主 訴として来院した血液透析患者で, 症状あるいは運動 負荷心電図から虚血性心疾患が疑われて冠動脈造影を 施行し, 冠動脈本幹に 25\%以上の狭窄を認めなかった 7 例を対象とした (透析群)。平均年齢は 58 歳 (38〜 72 歳)で，平均透析期間は 94 か月 (3〜192 か月)である. これに対し，対照群は同様に冠動脈造影を施行し冠動 脈本幹に $25 \%$ 以上の狭窄を認めなかった非腎不全患 者 8 例で, 平均年齢は 56 歳 (45〜65 歳)である。なお, 患者にはあらかじめ検査の内容を説明し同意を得た。

\section{2. 方 法}

冠動脈血流速の計測は, 大腿動脈アプローチから Judkins 法で冠動脈造影施行後, $5 \mathrm{~F}$ ガイディングカ テーテルの内腔を通じて, 0.014 インチ, $15 \mathrm{MHz}$ のド プラーガイドワイヤー（FloWire, Cardiometrics 社 製）を左前下行枝近位部に留置し，パルス・ドプラ法 にて行った。安静時の冠血流速は硝酸イソソルビド $2.5 \mathrm{mg}$ 冠動脈注入後に計測し, 平均最大流速 (average peak velocity : APV), 瞬間最大流速 (maximum peak velocity：MPV), 拡張期と収縮期の平均流速の 比 (diastolic systolic velocity ratio: DSVR) の 3 つ の指標を記録した。冠血流予備能は，塩酸パパベリン $10 \mathrm{mg}$ 冠動脈注入後に最大冠拡張が得られた状態での $\mathrm{APV}$ と安静時の APVの比として求めた。

また循環動態の指標としては, 安静時の心拍数, 平 均動脈圧に加え，スワン・ガンツカテーテルを用いた 熱希釈法による心係数と左室造影検査前の左室拡張終 期圧を用いた。

心エコー図検査は東芝 SSH-160A と $2.5 \mathrm{MHz}$ の 探触子を用い，傍胸骨左室短軸像において，Mモード 心エコー図法により以下の各指標を計測した。すなわ ち, 左室拡張終期径 (LVDd, 単位 $\mathrm{mm}$ ), 左室収縮終 期径 (LVDs, mm), 心室中隔厚 (IVST, mm), 左室 後壁厚 $(\mathrm{PWT}, \mathrm{mm})$ を計測し, 左室駆出率 $(\mathrm{EF}, \%$; $\left.\left(\mathrm{LVDd}^{3}-\mathrm{LVDs}^{3}\right) / \mathrm{LVDd}^{3} \times 10^{2}\right)$, 左室重量係数 (LVMI, g/m² $; 1.04\left\{(\text { IVST }+ \text { PWT + LVDd })^{3}-\right.$ $\left.\left.\left.\mathrm{LVDd}^{3}\right\}-14\right] / \mathrm{BSA}\right)$ をそれぞれ算出した。

運動負荷心電図検査は, Bruce または Schefieldの プロトコールに従ったトレッドミルによる症候限界性 の多段階運動負荷試験を行い，心電図上，水平または 下降型で $1 \mathrm{~mm}$ 以上の ST 低下を認めたもの, 上向き 型で $1.5 \mathrm{~mm}$ 以上の ST 低下を認めたものを陽性と判 定した。

なお, 透析患者は週 3 回の透析を行っており, 冠動 脈造影, 心エコー図検査および運動負荷心電図検査は, 透析施行日の翌日午前に施行した。この際, 全例至適 透析状態にあり，心不全症状を認めた例はなかった。

血液生化学的パラメータとしては, 血清へマトク リット $(\mathrm{Ht}, \%)$, 総コレステロール $(\mathrm{TC}, \mathrm{mg} / \mathrm{d} l)$,

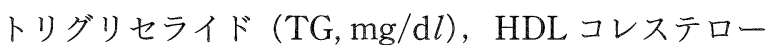
ル $(\mathrm{HDL}-\mathrm{C}, \mathrm{mg} / \mathrm{d} l)$ を測定し, それぞれ透析群と対 照群で比較した。

統計解析において, 結果はすべて平均値土標準偏差 で示し， 2 群間の比較は unpaired $t$ 検定を用い, $\mathrm{p}<$ 0.05 をって有意差とした。

\section{II. 結 果}

\section{1. 臨床像および循環動態の比較}

透析群と対照群における臨床像および循環動態の比 較を示す (表 1 )。透析群は非典型的な胸痛発作も含め 
表 1 Clinical characteristics of dialysis and control patients

1-A. Dialysis patients

\begin{tabular}{|c|c|c|c|c|c|c|c|c|}
\hline Case & Age & Sex & Symptoms & Ex-ECG & HR & MAP & LVEDP & $\mathrm{CI}$ \\
\hline 1 & 63 & $\mathrm{M}$ & $\mathrm{CP}$ & positive & 59 & 90 & 13 & 4.3 \\
\hline 2 & 72 & $\mathrm{M}$ & $\mathrm{CP}$ & Inconclusive & 65 & 100 & 13 & 3.3 \\
\hline 3 & 61 & $\mathrm{M}$ & $\mathrm{CP}$ & positive & 79 & 87 & 14 & 3.8 \\
\hline 4 & 69 & M & $\mathrm{CP}$ & Inconclusive & 65 & 105 & 16 & 3.5 \\
\hline 5 & 38 & M & $\mathrm{CP}$ & positive & 78 & 102 & 12 & 5.9 \\
\hline 6 & 59 & $\mathrm{~F}$ & $\mathrm{CP}$ & positive & 64 & 103 & 10 & 4.7 \\
\hline 7 & 43 & $\mathrm{~F}$ & atyp CP & positive & 71 & 110 & 12 & 4.8 \\
\hline Mean \pm SD & $58 \pm 13$ & & & & $69 \pm 8$ & $100 \pm 8$ & $13 \pm 2$ & $4.2 \pm 0.7$ \\
\hline \multicolumn{9}{|c|}{ 1-B. Control patients } \\
\hline Case & Age & Sex & Symptoms & Ex-ECG & $\mathrm{HR}$ & MAP & LVEDP & $\mathrm{CI}$ \\
\hline 1 & 65 & $\mathrm{M}$ & $\mathrm{CP}$ & positive & 73 & 80 & 12 & - \\
\hline 2 & 58 & $\mathrm{M}$ & $\mathrm{CP}$ & positive & 76 & 90 & 6 & - \\
\hline 3 & 59 & $\mathrm{M}$ & $\mathrm{CP}$ & positive & 58 & 97 & 12 & 3.2 \\
\hline 4 & 56 & $\mathrm{M}$ & $\mathrm{CP}$ & positive & 48 & 97 & 6 & 2.7 \\
\hline 5 & 52 & $\mathrm{M}$ & $\mathrm{CP}$ & positive & 55 & 133 & 12 & 3.6 \\
\hline 6 & 45 & $\mathrm{M}$ & $\mathrm{CP}$ & positive & 65 & 87 & 15 & 4.1 \\
\hline 7 & 53 & $\mathrm{M}$ & $\mathrm{CP}$ & Inconclusive & 76 & 103 & 7 & 3.7 \\
\hline 8 & 60 & $\mathrm{~F}$ & atyp CP & positive & 72 & 117 & 15 & 2.9 \\
\hline Mean \pm SD & $56 \pm 6$ & & & & $65 \pm 11$ & $101 \pm 17$ & $11 \pm 4$ & $3.4 \pm 0.5$ \\
\hline \multicolumn{9}{|c|}{ Ex-ECG : exercise electrocardiogram $\quad$ LVEDP $:$ left ventricular end-diastolic pressure $(\mathrm{mmHg})$} \\
\hline MAP : mea & arterial & essure & $\mathrm{mmHg})$ & : chest pain & & typ CP : a & ypical ches & pain \\
\hline
\end{tabular}
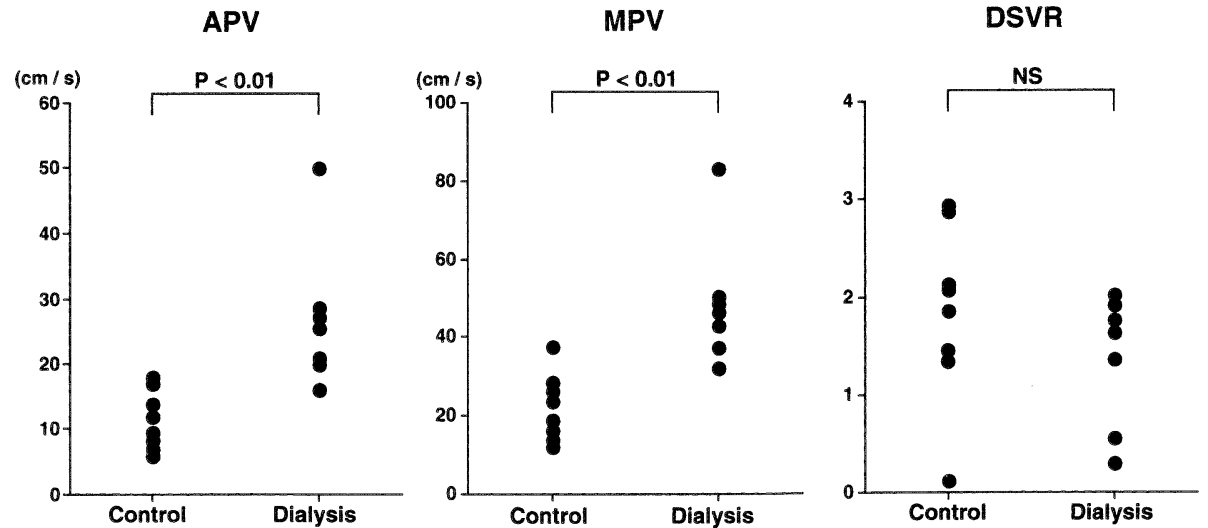

図 1 Comparison of basal coronary blood flow velocity between control and dialysis patients.

APV : average peak velocity MPV : maximum peak velocity DSVR : diastolic systolic velocity ratio

全例に自覚症状を認め，そのうち負荷心電図陽性が 5 例，負荷不十分なため判定不能が 2 例であった。これ に対し, 対照群では, 負荷心電図陽性が 7 例, 判定不 能が 1 例であった。また腎不全に至った原疾患は，全 例が慢性系球体腎炎で, 糖尿病の合併は認めなかった。 循環動態の比較では, 安静時心拍数が透析群 $69 \pm 8 /$ $\min$, 対照群 $65 \pm 11 / \mathrm{min}$ で有意差なく (N/S), 平均 動脈圧も透析群 $100 \pm 8 \mathrm{mmHg}$, 対照群 $101 \pm 17$ $\mathrm{mmHg}$ で有意差はなかった (N/S). 同様に左室拡張終 期圧は, 両群間において有意差を認めなかったが $(\mathrm{N} /$
S)，心係数は透析群が $4.2 \pm 0.7 \mathrm{l} / \mathrm{min} / \mathrm{m}^{2}$ で, 対照群 $3.4 \pm 0.5 \mathrm{l} / \mathrm{min} / \mathrm{m}^{2}$ に比較して有意に高值を呈してい た $(\mathrm{p}<0.05)$.

\section{2. 冠血流速の比較}

安静時の冠血流速について透析群と対照群の間で比 較した（図 1)。透析群の APV は $26.9 \pm 11.1 \mathrm{~cm} / \mathrm{s}$, MPV は $46.1 \pm 17.7 \mathrm{~cm} / \mathrm{s}$ で, 対照群の APV $11.7 \pm$ $4.3 \mathrm{~cm} / \mathrm{s}$, MPV $21.6 \pm 8.4 \mathrm{~cm} / \mathrm{s}$ に比較してそれぞれ 有意に高く $(\mathrm{p}<0.01, \mathrm{p}<0.01)$, 透析群では baseline の安静時冠血流速が増大した状態にあることが観察さ 

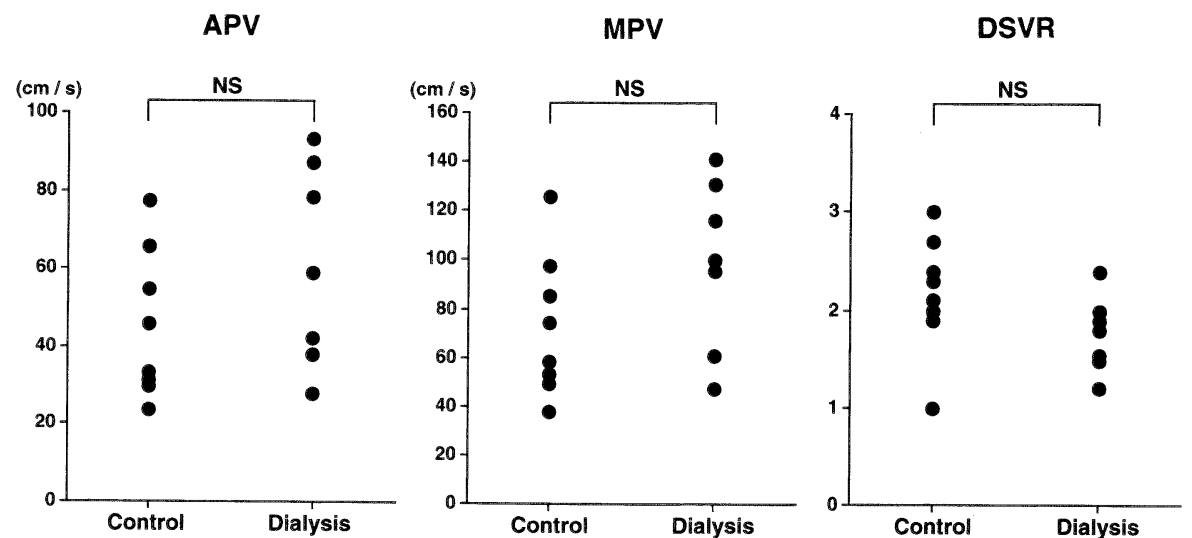

図 2 Comparison of hyperemic coronary blood flow velocity between control and dialysis patients.

APV : average peak velocity MPV : maximum peak velocity DSVR : diastolic systolic velocity ratio

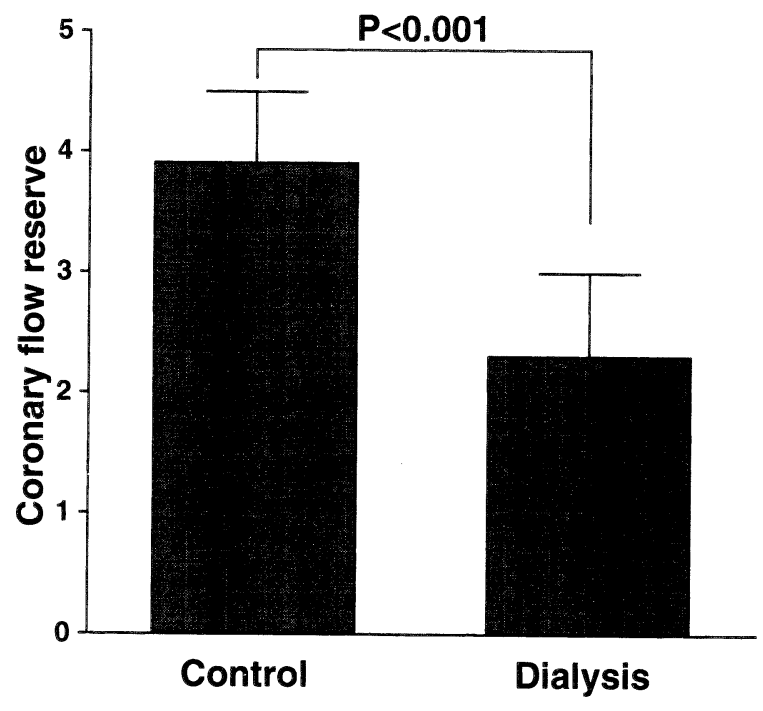

図 3 Comparison of coronary flow reserve between control and dialysis patients.

れた。また，DSVR は両群で有意差がなく $(\mathrm{N} / \mathrm{S})$ ，血 流パターンには差異を認めなかった。次に，塩酸パパ ベリン $10 \mathrm{mg}$ を冠動脈注入し最大冠拡張が得られた 状態における冠血流速について透析群と対照群の間で 比較した(図 2)。透析群の APVは $60.7 \pm 25.9 \mathrm{~cm} / \mathrm{s}$, MPVは $97.9 \pm 34.6 \mathrm{~cm} / \mathrm{s}$ まで増大したが, 対照群の APV $45.5 \pm 19.1 \mathrm{~cm} / \mathrm{s}, M P V 72.2 \pm 29.1 \mathrm{~cm} / \mathrm{s}$ に比 較して有意差を認めなかった $(\mathrm{N} / \mathrm{S}, \mathrm{N} / \mathrm{S})$ 。同様に DSVRも両群で有意差を認めなかった（N/S）.

\section{3. 冠血流予備能の比較}

透析群の冠血流予備能は $2.3 \pm 0.7$ で, 対照群の $3.9 \pm 0.6$ に対して有意に低值であった $(\mathrm{p}<0.001$; 図 3 ).
表 2 Echocardiographic measurements of dialysis and control groups

\begin{tabular}{lccc}
\hline & $\begin{array}{c}\text { Dialysis group } \\
(\mathrm{n}=7)\end{array}$ & $\begin{array}{c}\text { Control group } \\
(\mathrm{n}=8)\end{array}$ & $\mathrm{P}$ value \\
\hline LVDd $(\mathrm{mm})$ & $55.3 \pm 5.9$ & $49.5 \pm 7.3$ & $\mathrm{~ns}$ \\
LVDs $(\mathrm{mm})$ & $38.6 \pm 7.1$ & $33.2 \pm 6.4$ & $\mathrm{~ns}$ \\
IVST $(\mathrm{mm})$ & $11.0 \pm 0.8$ & $9.1 \pm 0.9$ & $\mathrm{p}<0.001$ \\
PWT $(\mathrm{mm})$ & $9.6 \pm 1.3$ & $9.6 \pm 0.5$ & $\mathrm{~ns}$ \\
LVEF $(\%)$ & $63.9 \pm 10.4$ & $71.6 \pm 8.8$ & $\mathrm{~ns}$ \\
LVMI $\left(\mathrm{g} / \mathrm{m}^{2}\right)$ & $171.8 \pm 28.0$ & $113.7 \pm 29.5$ & $\mathrm{p}<0.005$ \\
\hline & & \multicolumn{3}{c}{ Values are mean $+\mathrm{SD}$}
\end{tabular}

表 3 Laboratory findings of dialysis and control groups

\begin{tabular}{lccc}
\hline & $\begin{array}{c}\text { Dialysis group } \\
(\mathrm{n}=7)\end{array}$ & $\begin{array}{c}\text { Control group } \\
(\mathrm{n}=8)\end{array}$ & P value \\
\hline $\mathrm{Ht}(\%)$ & $29.4 \pm 5.6$ & $43.7 \pm 2.5$ & $\mathrm{p}<0.0001$ \\
$\mathrm{TC}(\mathrm{mg} / \mathrm{d} l)$ & $160.3 \pm 23.5$ & $227.4 \pm 29.1$ & $\mathrm{p}<0.0005$ \\
$\mathrm{TG}(\mathrm{mg} / \mathrm{d} l)$ & $125.2 \pm 39.3$ & $144.0 \pm 57.0$ & $\mathrm{~ns}$ \\
$\mathrm{HDLC}(\mathrm{mg} / \mathrm{d} l)$ & $38.9 \pm 9.1$ & $53.1 \pm 22.8$ & $\mathrm{~ns}$ \\
\hline & & \multicolumn{3}{c}{ Values are mean $\pm \mathrm{SD}$}
\end{tabular}

\section{Mモード心エコー図および血液生化学的パラメー 夕の比較}

透析群は対照群に比べ, LVDd, LVDs, PWT, EF に 有意差を認めなかったが, IVST, LVMI はそれぞれ有

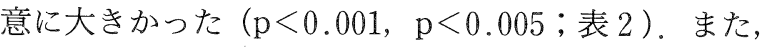
血液検査所見は表 3 に示したように，透析群において Ht 值と TC 值がそれぞれ有意に低值 $(\mathrm{p}<0.0001, \mathrm{p}<$ 0.0005）を呈していた。

\section{III. 考 察}

透析患者における心血管系合併症は, 生命予後を左 
右する重大な問題であり, 虚血性心疾患との関連につ いては样々な報告がみられるが ${ }^{325}$, 現在まで, 透析療 法自体が冠硬化症を促進するのか確立した結論は得ら れていない。しかし，多くの患者が透析導入時，すで に冠硬化症が進行した状態にあるとReisch ら ${ }^{6 /}$ は報 告しており, 腎不全保存期から冠危険因子の是正など 十分な管理が要求される。また Bossi ら ${ }^{71}$ は透析中に おける心筋虚血の誘因として, 循環血液量減少に伴う 冠血流量の低下, 血清カルシウムイオンの増加による 心筋酸素消費の増加など様々な機序を想定し，透析患 者の心筋虚血を捉えている。本研究では，透析患者に おける冠循環動態を明らかにするため, ドプラーガイ ドワイヤーを用い冠血流速および冠血流予備能を測定 し患者背景因子と比較検討した。

安静時冠血流速は，透析患者に抢いて対照患者に比 べ有意に増大していることが観察された。対象は冠狭 窄を認めない症例としており, 安静時冠血流速が増大 した原因としては，以下の点が考元られる，第一に透 析患者の心拍出量は, 対照患者に比べて有意に高值を 呈して㧍り，腎性貧血に伴う心拍出量の増加が挙げら れる。今回の検討では, 貧血の程度と安静時冠血流速 の間に，有意な相関は認めなかったが，血清へマトク リット值が低值の例で安静時冠血流速は高い傾向に あった。第二に高血圧症, 二次性副甲状腺機能元進症 ${ }^{8)}$ などに伴う左室肥大が原因に考元られる。他に, 動静 脈シャント自体の冠血流速に対する影響についても考 慮しなければならないが, 今後, 動静脈シャントを持 たない持続的腹膜透析患者との比較検討が必要であ る。一方，近年，内皮由来弛緩因子の本体として注目 される一酸化窒素 $(\mathrm{NO})^{9}{ }^{9}$ の透析患者に抢ける動態に ついての報告も散見され，NO の最終代謝産物である NOx が健常者平均に比べて高值であり, NO 産生六進 を伴う何らかの病態の存在が示唆されている ${ }^{10)}$. 透析 患者の冠微小循環系においても NOが関与し, 安静時 から十分な冠血流を維持するような方向で働いている 可能性も否定はできない,

冠血流予備能に関しては 3.0 以上が正常と報告され ているが ${ }^{111}$, 透析患者は $2.3 \pm 0.7$ と正常值以下で, 対 照患者 $3.9 \pm 0.6$ に対しても有意な低下が認められた。 一般に冠血流予備能が低下する成因には，basal flow がすでに上昇している場合と最大冠拡張時の peak hyperemic flow が低下する場合の二つが考えられる. 今回の検討結果加透析患者の冠血流予備能低下は, 安静時冠血流速 (basal flow) の増大が主たる原因と結 論づけられたが，このことは透析患者における $\mathrm{mi}$ crovascular disease の存在を否定するものではない.
また，以前から透析患者は非腎不全患者に比へ，冠動 脈の石灰化が強いことが指摘されているが12,13)，冠動 脈石灰化が冠血流や冠微小循環系へ及济寸影響につい ても検討する必要がある。

以上，透析患者の冠血流予備能の評価にあたり，貧 血, 左室肥大, 動静脈シャントの影響をどのように考 慮すべきか課題は残されるが，今回用いた方法で評価 する限りにおいては冠血流予供能が低下している点は 事実で，透析患者の虚血性心疾患を考元る場合には， 留意する必要がある。 さらに, 貧血の是正により冠血 流予備能の改善はみられるのか, 冠血流予備能沅冠動 脈石灰化や NO が関与するのか, 今後の検討課題と思 われる。

\section{結 論}

透析患者における冠血流速および冠血流予備能を測 定し, 以下の結論を得た。

1. 安静時の平均最大流速扔よび瞬間最大流速は, 対照患者に比し，透析患者で有意に高值を示した。

2. 塩酸パパベリン $10 \mathrm{mg}$ 冠動脈注入後のこれら の流速は，両群間において有意差を認めなかった。

3. 冠血流予備能は, 対照患者に比べ透析患者で有 意に低值であった。

4. 透析患者は対照患者に比し, 左室重量係数が大 きく，貧血を呈していた。

以上より，透析患者では冠血流予備能が低下してお り, その原因には安静時冠血流速の増大が重要な因子 と考えられた。

本論文の要旨は, 第 41 回日本透析医学会総会 (名古屋) および第 45 回日本心臟病学会学術集会 (札幌) にて報告し た. 本研究は, 平成 6 年度厚生省循環器病研究委託事業「透 析患者の循環器合併症の実態と対策に関する研究」(班長木 村玄次郎）の一部として行われた。

\section{文献}

1）日本透析医学会統計調查委員会：わが国の慢性透析療 法の現況（1995 年 12 月 31 日現在）。透析会誌 $30: 1^{-}$ 25, 1997

2) Doucette JW, Corl PD, Payne HM, Flynn AE, Goto M, Nassi M, Segal J : Validation of a Doppler guide wire for intravascular measurement of coronary artery flow velocity. Ciruculation $85: 1899-1911$, 1992

3) Lindner A, Charra B, Sherrard DJ, Scribner BH : Accelerated atherosclerosis in prolonged mainte- 
nance hemodialysis. N Engl J Med 290:697-701, 1974

4) Rostand SG, Gretes JC, Kirk KA, Rutsky EA, Andreodi TE: Ischemic heart disease in patients with uremia undergoing maintenance hemodialysis. Kidney Int 16:600-611, 1979

5) Castro L, Hofling B, Hassler R, Hillebrand G, Land W, Kreuzer E, Kemkes B, Gurland HJ, Erdman E : Progression of coronary and valvular heart disease in patients on dialysis. Trans Am Soc Artif Intern Organs $31: 647-650,1985$

6) Reisch C, Mann J, Ritz E : Konversionsenzymhemmer in der antihypertensiven behandlung niereninsuffizienter patienten. Dtsch Med Wochenschr 112 : 1249-1252, 1987

7) Bossi M, Saviotti M, Caprari M, Vendemia F : Ischemic Heart disease and its management in uremic patients on hemodialysis. Contr Nephrol $61: 171^{-}$ 180, 1988

8) Sato S, Ohta M, Kawaguchi Y, Okada H, Ono M, Saito H, Utsunomiya M, Tamura T, Sugimoto K,
Takamizawa S, Tanaka H, Shigematsu T, Tojo K, Sakai O:Effects of parathyroidectomy on left ventricular mass in patients with hyperparathyroidism. Miner Electrolyte Metab 21 : 67-71, 1995

9) Palmer RMJ, Ferrige AG, Moncada $S$ : Nitric oxide release accounts for the biological activity of endothelium-derived relaxing factor. Nature $327: 524$ $-526,1987$

10）大山信雄, 益田真理, 久我由紀子, 新井邦彦, 本宮善 恢, 土肥和紘, 岡島英五郎：維持透析患者における一 酸化窒素 (NO) 代謝産物の測定. 透析会誌 $29 ： 29-35$, 1996

11) Sibley DH, Millar HD, Hartley CJ, Whitlow PL : Subselective measurement of coronary blood flow velocity using a steerable doppler catheter. J Am Coll Cardiol $8: 1332-1340,1986$

12) Parfitt AM : Soft tissue calcification in uremia. Arch Intern Med 124: 544-556, 1969

13）宇都宮正範：維持透析患者における冠動脈病変と石灰 化に関する研究一冠動脈造影所見と背景因子の解 析一。日腎会誌 $38: 155-163,1996$ 